\title{
НАШЕ НОВИНЕ: \\ ПОЛИТИЧКИ, ГОСПОДАРСКИ \\ И ДРУШТВЕНИ ЛИСТ 1943-1944.
}

\section{Сажетак}

Haше новине су биле, пре свега, политички лист у којем су се могле наћи и рубрике из области привреде и друштвених питања. Превасходни циљ покретања овог листа је био наставак већ покренуте кроатизације Буњеваца и Шокаца, а за време окупације Града Сомбора у Другом светском рату од стране мађарских фашистичких трупа. Лист је излазио у Сомбору од 2. априла 1943. до 6. октобра 1944. године. Покретач, издавач и одговорни уредник листа био је Грга Вуковић, адвокат из Сомбора. Лист се налази у фонду завичајне периодике у Градској библиотеци „Карло Бијелицки” и представља сведочанство времену и одређеним, превасходно националистичким, односно политичким циљевима, који су подржавани од стране окупатора, како би се на овај начин и Бачка учинила, барем привидно, хрватским историјсконационалним подручјем, као што је већ и фактички то Срем постао, тада у саставу Независне Државе Хрватске. Чланци на које читалац може наићи представљају доказ о третману одређених националних и етничких група са циљем преквалификовања већ дубоко укорењених и вековима заступљених етничких заједница које је Хрватска сељачка странка намеравала преобратити у Хрвате. Деловање Грге Вуковића, како у овом листу, тако и на месту заступника у будимпештанском сабору, али и у његовом новинарском позиву било је управо на пољу буђења националне свести Хрвата, борби против декроатизације Буњеваца и Шокаца и успостављања што бољих односа са окупационим снагама, што је евидентно из садржаја листа. Аутор чланка имао је намеру осветлити овај део, колико сомборске, толико и националне историје, указати на тенденциозни садржај листа и улогу Наших новина у ратном периоду, те сачувати од заборава историјске чињенице важне за правилније и боље разумевање савремених проблема и тенденција које

1 Градска библиотека „Карло Бјелицки“, Краља Петра I, 25000 Сомбор vladimirjerkovic@yahoo.com 
постоје у сфери политичког деловања одређених мањинских заједница у Републици Србији данас.

Кључне речи: Наше новине, др Грга Вуковић, Хрвати, Шокци, Буњевци, Сомбор, Други светски рат.

\section{Увод}

Вековима тесно везан за Србе, буњевачки народ је у слози са српским на војвођанским поднебљима Бачке, али и Барање, упоредо заживео и опстојавао све до пред крај Другог светског рата, када је једном декларацијом² укинуто право, односно могућност, самоодређења и изјашњавања према националности Буњеваца и Шокаца, као засебног и својственог народа са неотуђивим правом самоопредељења, односно када је кроатизација ових народа и системски била настављена, овога пута од стране политичких актера тога времена а у новононасталој Федеративној Народној Републици Југославији. ${ }^{3}$ у овом раду приказаћаемо управо део историје, поткрепљене доказима, који сведочи о ратном раздобљу, политичком опортунизму, агитацији и пропаганди која се спроводи за време окупације Бачке од стране мађарских фашистичких трупа.

Међутим, сведоци смо данас да су обичаји, култура и језик сачувани, те да смо сада управо у времену процвата, можда боље и примереније речено поновне актуелизације буњевачке националности и то најинтезивније, готово искључиво, у оквирима Републике Србије, у поредеђењу са околним државама у региону, у којима је овај народ, такође, вековима настањен. Историјска чињеница постојања буњевачке заједнице јесте и штампана периодика, пет листова који су излазили у Сомбору, од којих је последњи у низу настао у јеку Другог светског рата.

2 Реч је о декларацији Главног народноослободилачког одбора Војводине, одељења за унутрашње послове, број 1040/1945 од 14.5.1945. г. донете у Новом Саду у којој, између осталог, јесте наређено издавање нових легитимација за Буњевце и Шокце у којима се у одељку за националност употребљава реч "Хрватско“.

3 Више о томе видети https://www.subotica.com/vesti/bunjevacki-savet-trazidonosenje-deklaracije-o-ponistavanju-akta-nasilne-asimilacije-bunjevaca-id31962.html. 
Naše novine, ${ }^{4}$ политички, привредни и друштвени лист, излазио је у Сомбору од 2. априла 1943. до 6. октобра 1944. године. Издавач и одговорни уредник листа био је Грга Вуковић, ${ }^{5}$ адвокат из Сомбора и народни заступник у будимпештанском парламенту. Лист је био штампан латиницом, у ротационој штампарији Јосипа Бошњака на истој адреси где се налазило и уредништво, и био је намењен Хрватима, Буњевцима и Шокцима. Имао је тираж од 5.000 примерака. Штампан је на осам страна и садржавао је илустрације.

\section{О Нашим новинама}

На страницама Наших новина читалац је наилазио на сталне рубрике: Преглед вањске ситуације, ${ }^{6}$ Политичке висти, Господарство, Спорт... У сваком броју, поред рубрике Занимљивости, доносио је прозне и лирске текстове, стално позивајући на сарадњу младе таленте. Од сталних сарадника треба споменути Антуна Карагића, Матију Колара, Ивана Димића, Петра Царева, једног од уредника листа, и Ивана Мироницког. Грга Вуковић је у уводнику првог броја између осталог рекао:

„Покретајући овај лист, дајемо му наслов Наше новине са искреном жељом, да то буду одиста наше новине са надом и увирењем да ће Hame новине бити новине свију нас и за све нас, који припадамо буњевачком и шокачком пуку..."

У редакцији Наших новина, у улици Чихаш Бенеа бр. 3 у данашњем насељу Млаке, односно Онча, на периферији Сомбора, током 1944. године штампао се и његов додатак под именом Наш календар. У броју 30, прве године излажења листа на његовој другој страни (22. октобар 1943.), уредништво Наших новина је објавило вест о добијању дозволе за издавање буњевачко-шокачког календара за 1944. годину. Главна пажња у Календару била је посвећена буњевачко-шокачкој култури и обичајима.

4 Одлука је аутора чланка да назив листа само у првом помињању наводи у оригиналу и на писму на којем је лист штампан.

5 У понеким изворима уместо Грга наведено је Грго.

6 Оригиналне називе рубрика пишемо према српском правопису, онако како се изговарају, али без превођења или уподобљавања са стандардизованим формама данашњег језика. 


\section{Уредничка концепција др Грге Вуковића и сврха издавања Наших новина}

При овим општим подацима, које смо управо изнели пред читаоца, нису најјасније и на најпрецизнији начин изнете чињенице које говоре много о раду и политици др Вуковића, а узимајући у обзир да је лист излазио искључиво за време окупације Сомбора. У првом обраћању читаоцима јасно је да и шокачки и буњевачки живаљ треба да представља читалачку публику али није превише тешко опазити да је реч о пре свега хрватству, које некако обједињује ове националне групе, а по кључу припадништва Римо-католичкој црквеној заједници. Не можемо се отети утиску да покретач и главни уредник листа др Грга Вуковић ипак чини озбиљну политичку агитацију, а што је евидентно у сваком наредном броју листа. Штавише, уредник у првом броју на самом крају пише:

„Поздрављајући са овим мислима наше драге читаоце, желимо истаћи, да ће Haше новине за вриме овог свитског рата са овим редцима и завршити политизирање. Данашња вримена нису за политику, нису за политичка расправљања, јер она могу врло лако да створе раздор међу људима, док је наш циљ да Буњевци и Шокци буду сложни, јер само слогом ћемо моћи постићи наше жеље. "

Већ и по првом читању овога цитата јасно је да рођени Чонопљанац, дакле човек рођен у насељу надомак Сомбора, у потпуности изоставља помињање Срба суграђана, а за шта не можемо прихватити да нема тенденциозне карактеристике. Друго, др Вуковић уређује лист који излази у прилично јаком тиражу од 5.000 примерака, када знамо то да је намењен искључиво одређеној популацији. И треће, али и најупечатљивије, јесте управо контрадикторност уредникових изјава. Наиме, у сваком наредном броју објављиване су политичке вести, извештаји са ратишта и друго у вези са неприликама у свету, али је и најнеупућенијем читаоцу већ на први поглед јасно да је свакичланак чисто пропагандистички, да су вести конципиране тако да се ствара подршка и/или одобравање у буњевачком и шокачком народу за све оно што окупатори чине, како у Бачкој тога времена, тако и широм Европских бојишта. Помињање немилог рата на самом почетку, изрази дубоке захвалности Угарској држави, као да иста на овом простору није престала да буде власт по завршетку Првог светског рата, уз упућивање сународника на приклањање окупационој 
војсци и управи пропраћено је освртом на стару постојбину Буњева и Шокаца, а о чему др Вуковић пише:

„Нас Буњевце и Шокце судбина је смистила у овај крај свита. Наше досељење у Бачку према аутентичним хисторијским подацима извршено је у годинама 1686-1687, каде су наши предци под упутством Фрањеваца, као својих духовних вођа, око 150.000 напустили стару постојбину: Далмацију и Херцеговину..."

Даље, у наставку цитираног пасуса, др Вуковић пише о упућеној молби и дозволи наклоњеног им цара да се настане и заснују трајно своје животе на овом подручју. И заиста, уредник у сваком броју спаја неспојиво, поставља рубрике посвећене поезији, прози, такмичењима спортским, саветима за домаћице, чланке о пољопривреди, оглашавања за продају, док је централни део сваког броја стање на фронтовима и важније вести у вези са одлукама окупационе фашистичке управе. Дакле, садржај са јасном намером извештава одабрану јавност (буњевачку и шокачку) о тренутном стању које иде на руку управо онима који пропагирају своје идеје и планове народу који је вековима уназад настањен на овим просторима заједно са српским народом, а који се од њега разликује готово само и искључиво по припадности другом хришћанском обреду. У таквим околностима Другог светског рата, у јеку борби и тираније, којој су се многи свесрдно прикључили, излазе Наше новине, добијају дозволу за рад, омогућено никада јефтино штампање и пласирање, што све иде у прилог претпоставци да су морале одговарати и мађарскимфашистичким окупационим властодршцима, али и то да су овим новинама појединци покушавали донекле уплести интересе новоформиране Независне државе Хрватске, као актера, у области припојеној Мађарској, управо инструишући јавно мњење и актуелизујући постојање Хрвата у овом делу окупиране Краљевине Југославије. Као поткрепљење овој тврдњи стоји и податак да се Вуковић већ у раној доби почео бавити политиком, те да је био повезан са суграђанином Антуном Матарићем, у којем је имао истомишљеника по ставу да су Буњевци-Хрвати, неодвојиви део хрватског народа. Пре распада Аустро-Угарске био је заступник у будимпештанском парламенту и према томе није тешко за поверовати да је стекао и задржао бројне везе са политичарима у главном граду Мађарске, односно и даље неговао оне везе које су могле омогућити да у ратним годинама стекне и материјалне, финансијске али и правне услове и дозволе за 
ширење своје политике. Програм Хрватске републиканске сељачке странке, која је тај назив добила 1920. године, је осим код Вуковића и Матарића, у Сомбору нашао присталице и у Ивану Бошњаку, Шими Карасу, Јосипу Колићу, Фрањи Малбашићу, Фрањи Матарићу, Фрањи Мијићу, Јосипу Палићу, Антуну Парчетићу, Јосипу Стрилићу, Антуну Вујевићу и другима. ${ }^{7}$

Како не бисмо одмах сада улазили у уредникову биографију и друге околности, за шта ће у каснијем тексту бити посвећено речи, наставимо анализу онога што је уредник Вуковић бирао у првим бројевима новина. Оно што се некако посебно запажа у секцијама посвећеним за оглашавање и рекламирање је то да нема огласа српских занатлија, продаваца али ни немачких, што оставља утисак да је реч и о локал-национал-патриотском односу према економији унутар вароши, указујући на повољности код продаваца Буњеваца и Шокаца. Такође, индикативно је и често помињање Суботице којој Сомбор гравитира, према др Вуковићу, која је често помињана или је саставни део чланака у новинама, што сасвим одговара територијалној управи коју су мађарски-фашистички окупатори у то време са успехом спровели, и не само својим снагама него придруженим напорима домаћих хомведа, колоборациониста, добровољаца и других, попут фолксдојчера који су на најразличитије начине помагали интеграциују нове власти, прогоне неистомишљеника и све друго толико нам познато.

Хвалоспеви диктатору Хортију сведоче и потврђују претходне тврдње, а у даљем тексту покушаћемо приближити читаоцу садржај листа и оно што је најважније за предмет истраживања овде. У Сомбору је 9.4.1943. изашао је број 20 Наших новина, а са насловне стране цитирамо аутора чланка потписаног као Ц. За потребе овог рада издвајамо наслов и уводни део чланка:

\section{„Хорти Миклош Регент Краљевине Мађарске Патрон Буњеваца}

Буњевци и Шокци у Мађарској добро познају велике државничке способности регента Краљевине Мађарске... "

7 Према списима Радивоја Стоканова сачињаваним за потребе секције интернет сајта Градске библиотеке „Карло Бијелицки” у Сомбору на којој су базе података Дигиталне збирке. Више о томе видети: http://www.biblioso.org.rs/digitalna_zbirka.php?lng=ci 
Да би у наредном пасусу писало:

„У данашњем броју Наших новина упознаћемо нашу јавност са поближом сликом из свакидањег живота и рада тога човика, који игра прву улогу у мађарском државном животу, па тиме и у животу наших Буњваца и Шокаца. "

А пред крај, и након афирмативног описа друштвених активности Хортијеве супруге, аутор чланка пред крај истиче и то да:

„Као државни поглавар регент се строго придржава Устава и не допушта та итко у том погледу на њега утиче. "

Оно што је централна тема овог рада јесу чланци и фељтони који су се тицали друштвеног и политичког живота и намера представника ${ }^{8}$ Буњеваца и Шокаца, а дефакто понајвише њих као Хрвата, за шта многи од њих себе никад нису сматрали, све са циљем што бољег позиционирања у будућој констелацији снага, а након окончања рата и победе Сила осовине, коју су прижељкивали. Наравно, не тврдимо да је писано у ступцима ових новина одраз расположења и мишљења свих католика Словена на подручју Сомбора и околине. Међутим, веома је важно истаћи мотиве, указати на врсту политичке агитације појединиаца и објективно сагледатионоштојеједним снажниммедијем у времену смрти, депортација, нестабилности, страха и стрепње, група припадника једног народа налазила за сходно објављивати, чиме је понајвише оставила доказ о сопственом концепту, смерницама и циљевима којима је таква, слободно и морамо рећи, сомборска а хрватска политика, налазила за сходно, да у таквим приликама и чини. Иако је евиднетно да је реч о опортунизму, нећемо занемарити све написано, у нади да ће неке друге генерације читалаца, којима и сами припадамо, сагледавајући чињено, боље разумети континуитет суживота буњевачког, шокачког и српског народа на овим просторима. Избегавајући осврт на Наше новине остали бисмо ускраћени за део завичајне историје у периоду који је представљао још једну велику прекретницу у првој половини двадестог века.

Како су ове новине у непосредној вези са ликом Грге Вуковића, будући да видимо да непотписани чланци морају махом бити из његовог пера, његовог превода из других, вероватно мађарских новина

8 Овде смо у недоумици да ли реч представник ставити под наводнике, будући да те особе нису биле ни легитимни али ни фактички представници ни једног од три народа именом ословљена којима се уредништво обраћало. 
тога времена, ${ }^{9}$ онда смо дужни и о овом човеку представити одређене биографске податке, а све у најбољем разумевању контекста из којег произилази та и таква уредничка концепција Наших новина.

\section{Др Грга Вуковић, уредник Наших новина}

Грга Вуковић је рођен у Чонопљи код Сомбора 10. октобра 1894. године. После завршених студија права у Пешти, живео је и радио као адвокат у Сомбору. Још као млад правник почео се бавити политиком. Када је Сомборац Антун Матарић током 1923. године, боравећи уЗагребу, ступио у контакт са браћом Радић и прихватио њихова начела оустројству Хрватске сељачке странке (у даљем тексту ХСС), по коме се национално питање Буњеваца не може задржати ван утицаја XCC, у Сомбору је у Грги Вуковићу нашао истомишљеника, који је такође сматрао да су сомборски Буњевци у ствари Хрвати, и да се ни по коју цену не могу одвојити од свог националног стабла. ${ }^{10}$ Према томе, евидентан је став који провејава транспарентно у новинама, иако додворавање и Буњевцима и Шокцима бива настављано само да би се понекад, готово стидљиво оно објединило у називу-Хрват. Вуковић је, као уредник, сматрао да ваља и оно што је Црна хроника данас да објави у ступцима вести, иако се баш ова коју смо издвојили, догодила у Суботици, а која тобоже сведочи о малом ексцесу, мада историја памти да је далеко већих и бројнијих крвопролића било на очиглед свих, попут стрељања у дворишту зграде Жупаније у Сомбору, у дворишту Светођурћевског харама и депортација о којима нема помена у овим новинама. Па ипак, Вуковић је сматрао да и оваква вест треба да се нађе у другом броју из 1943. године:

\section{„Драгутин Думић осуђен на седам година робије}

У Радићевој гостионици у Сабадки, посвадили су се Драгутин Думић, земљорадник и Миклош Катринка. Свађа је заузела толико маха, да је Думић ударио Катринку прво штапом неколико пута, а после изва-

9 Овде мислимо на политичке вести и вести са ратишта и фронтова које су највероватније дословно превођене из неког другог извора доступног у Сомбору у том периоду.

10 Извор: http://www.biblioso.org.rs/nase_novine.php?id_grupa=3\&lng=ci преузето 2.12.2016. 
дио нож и више пута га зарио у тило Катринке, који је ускоро издахнуо. Јучер је суд за ово дило Думића осудио на седам година робије и на 10 година губитка часних права."

Но, вратимо се на политичку позадину и личну историју др Вуковића. Војвођански покрет, чији је активни члан био и Грга Вуковић, после увођења шестојануарске диктатуре се мукотрпно развијао и поред тога што је представљао темељ удружене опозиције у Бачкој. Највећу афирмацију програм ХСС и хрватство у Бачкој доживеће касније управо у овом Покрету после усвајања Мачековог политичког програма - Загребачке пунктације, 7. новембра 1932. године. Тадашњи вођа Покрета био је Сомборац Дуда Бошковић. Током 1934. године Грга Вуковић, који се иначе и бавио новинарским радом, почео је изадавати лист Даница, али је лист поживео само неколико месеци. На Оснивачкој скуштини Хрватског културног друштва Мирољуб у Сомбору ${ }^{11}$ одржаној 6. децембра 1936. године,

11 Завод за културу војвођанских Хрвата на своме званичном сајту, од 25.6.2012, објављује вест о Обележавању 150 година од рођења Анте Еветовића Мирољуба. Из текста преносимо део новинарског пасуса госпође Злате Васиљевић и цитат излагања г. Мате Матарића: "Обиљежавању 150. обљетнице рођења Анте Еветовића Мирољуба била је пригода да се нешто каже и о хрватском друштву „Мирољуб” у Сомбору. Предсједник ХКУД-а 'Владимир Назор' Мата Матарић рекао је да су оснутку овог друштва претходиле несугласице у „Буњевачком колу” јер хрватски оријентирани чланови тог друштва нису били више пожељни у ‘Бњевачком колу` гдје су били од његова оснутка 1921. године."

„Били су понесени националним духом, омасовили су се и плашили су их се они који су себе звали Буњевцима. Постојале су шансе да Хрвати постану у управи бројнији, а 1932. године када су Хрвати и добили већину, чак је интервенирала полиција како би наводно провјерила регуларност избора који су проглашени неважећим. Хрвати су послије избора, 1935. године, били пред алтернативом - остати у 'Буњевачком колу' и пасивизирати се или иступити и основати засебну организацију. Превагнуло је друго размишљање и Антун Матарић и његови истомишљеници напустили су 'Буњевачко коло' и у прво се вријеме почели окупљати у Дому 'Свете Цецилије', гдје је било сједиште Крижарскога братства. Оснивачка скупштина је одржана 1936. године када је основано Хрватско културно друштво 'Мирољуб'. Друштво је конституирано, али је пригодом оснутка било сталних сметњи, а разлог тому била је сумња власти у патриотски став Хрвата, јер када је краљ Александар 1929. године увео диктатуру, у ‘Буњевачком колу’ је предложено да се владару упути телеграм солидарности и израза поштовања. Тому су се успротивили будући челници 'Мирољуба' и предсједник Хрватске сељачке странке, но телеграм је ипак упућен", указао је Матарић на повијесне околности које су претходиле оснутку Хрватског друштва 'Мирољуб'. Извор: http://www.zkvh.org.rs/index.php/vijesti/vijesti-iz-zajednice/1168-u-subotici-i-somboruobiljeena-150-godinjica-roenja-ante-evetovia-miroljuba преузето 4.12.2016. 
у његов Управни одбор је изабран и адвокат Грга Вуковић. Оснивање овог Друштва било је круна активности потврде осећања неколицине Буњеваца да су Хрвати. Исте године Вуковић даје прилог и позајмицу Друштву ради куповине зграде у Малоцрквеној улици за смештај Хрватског културног друштва Мирољуб. ${ }^{12}$

Стварањем Бановине Хрватске 1939. године политичка групација звана Војвођански покрет, којој је припадао и Вуковић иначе и члан XCС-a, запала је у кризу. Питање целовитости Бачке чије је северозападне делове тражио Мачек, поделио је Покрет. Са једне стране су биле вође XСС, а са друге Срби и Мађари. Поред тога и међу Хрватима се све више осећала подела између суботичког сенатора, иначе презимењака Грге Вуковића, који се залагао за целокупност Војводине. Августа 1940. године долази до споразума Цветковић - Мачек. У име локалног руководства XCС-а, тадашњег сомборског градоначелника Ивана Матарића, посећује управо Грга Вуковић и преноси му сугестије др Влатка Мачека о потреби опште сарадње на нивоу града. ${ }^{13}$

Мађарска војска у Бачку улази 12. априла 1941. године. У складу са негирањем хрватске националности уБачкој, мађарске власти фаворизују буњевачко национално опредељење. Затекнувши себе у новонасталом стању, руководство ХСС-а у Суботици се пасивизирало, док се у Сомбору Грга Вуковић у потпуности приклонио мађарским властима. Отуда и тако позитиван и афирмативан однос у чланцима његових новина о мађарској власти и политици, отуда и та концепција осмишљена да утиче на свест и размишљања пука, отуда такав избор и такав садржај који је стремио произвести код читалаца макар осећај прихватања нових владара. Колико је подршка колоборационизму и чак другим земљама, њиховим савезницима, била део уредничке концепције сведочи читав Преглед вањскополитчке ситуације, ${ }^{14}$ али и неочекивани чланци, спорне важности за читаоце у Бачкој, попут овог:

\section{„Политичке Вијести}

Бугарски краљ Борис је у суботу поподне у 16:28 сати преминуо... Разне гласине и у иноземству проширене вијести по којима

12 Према јавном обраћању Радивоја Стоканова на отварању изложбе Ка веку и по сомборске периодике.

13 Исто.

14 Текст овог чланка доступан је на http://www.biblioso.org.rs/digitalna_zbirka_ prikaz.php?lng=ci\&id=1628 
се смрт краља Бориса доводи у везу са неким 'спољњим узроцима' Бугарска телеграфска агенција најодлучније демантује."

Грга Вуковић је у име Хрватског културног друштва Мирољуб одлазио у посете код војног комаданта Сомбора, генерала Агоштона Сентандреија на поклоњење. То му ипак није помогло да избегне хапшење од стране мађарских власти у лето 1941. године. Ухапшен је због оптужбе за одржавање веза са усташким властима из НДХ. Међутим, хапшење је било исценирано са циљем да окупаторске полицијаске снаге нађу међу Хрватима поузданог човека који ће се ставити на чело буњевачко-шокачког покрета, чији ће циљ бити изражавање послушности и лојалности мађарском регенту Хортију.

По изласку из затвора Грга Вуковић је отворено стао на страну окупатора. Када је Мирољуб држао прело почетком 1942. године, Грга Вуковић је наговарао председника Друштва Антуна Матарића, да се присутнима прво обрати на мађарском језику, што је Матарић одбио. Уместо њега на мађарском је говорио Иван Мироницки, адвокат и истомишљеник Грге Вуковића. Незадовољни чланови Мирољуба, под образложењем да је повредио правила Друштва, забрањују активан рад Грги Вуковићу у Друштву. Тиме је и пропала жеља Мађара да наметну свог човека Хрватима У Сомбору.

Првог априла исте године, потписом председника Друштва, Антуна Матарића и секретара Густава Богдана, из Мирољуба бива искључен Грга Вуковић. Неки чланови су пошли за њим, као нпр. др Иван Мироницки, адвокат Антун Вујевић, земљорадници Јосип Парчетић, Грга Пекановић, Људевит Острогонац, трговци Јоса Стрилић и Антун Парчетић и други. У пролеће 1943. године мађарске власти забрањују је деловање Мирољуба.

Национало и политички дезорјентисан др Грга Вуковић је октобра 1944. године, заједно са својим сарадником Антуном Вујовићем, напустио изадаваштво и уредништво Наших новина и побегао из Сомбора. Отишао је у Минхен, из кога је после рата учествовао у политичкој кампањи против Југославије. Грга Вуковић је умро у Минхену 23. септембра 1956. Године. ${ }^{15}$

15 Ако је веровати списима Радивоја Стоканова, које је спремао за Изложбу Ка веку и по сомборске периодике, у Хрватској ревији из 1957. године, објављен је некролог поводом смрти Грге Вуковића. Хрватска ревија је хрватски културнополитички часопис. Основали су га 1950. године Винко Николић и Антун Бонифачић. 


\section{Закључак}

Уколико узмемо у обзир све до сада наведено можемо доћи до закључка да је др Вуковић био донекле сналажљив у политици, у датим околностима, али и да његова релативна дезоријентисаност није последица само промена које су снашле све у том времену, него је и резултат немања довољно упоришних тачака за оно што је прилично посвећено чинио, а такво је јер изгледа да је читав животни век посветио идеји. Оно што је са убеђењем личним и дубоким покушавао да пренесе на друге, можемо рећи инфицира својим друштвено-политчким ангажманом, данас знамо да није постизао са већим успехом, а о чему сведчи и његово искључење из локланог хрватског друштва. Његова стремљења су јасно прохрватска и представљају окосницу деобе или упрошћавања буњевачке $и$ шокачке националне мањине вековима присутне на просторима бачке на заједнички именилац - Хрвати. Јасно је и да је био противник југословенске идеје, јасно је да је додворавајући се мађарским властима налазио само начина остварења хрватских националних циљева, прецизније, страначке опције којој је припадао (ХРСС), дакле циљева самопрокламованих представника народа којем је веровао да и сам припада, те му је сходно томе и та дужност припала, да у Сомбору покуша урадити оно што је својим јавним деловањем и откривао. Да су фашистичке власти сматрале да је реч о опасном и по њих штетном деловању, ове новине не би потрајале, односно не би ни заживеле. Оно што са ове тачке гледишта можемо сматрати тенденциозним писањем, удворништвом и чак дефетизмом можемо читати у кратким чланцима који су највероватније требали послужити слабљењу морала или коначном преласку на ставове које заговарају Наше новине, а што видимо из наслова чланка од 29.10.1943, са четврте стране:

\section{„Ни један немачки војник не би дошао на Балкан да га Срби} нису изазвали, рекао је Хитлер Генералу Недићу..."

При крају овога рада дужни смо и следеће чињенице навести, а када говоримо о сомборској периодици на буњевачком језику. На буњевачком су штампана гласила махом политичке садржине, мада су садржавала разнородне прилоге, али значајна су због тога што су писана

Први број часописа је изашао 1951. године. У раздобљу од 1951. до 1990. године излазио је у иностранству као часопис хрватске политичке емиграције, што онда готово аутоматски значи да је Вуковић присвојен од стране усташког покерта у емиграцији као важна историјска личност са заслугама довољно важним за хрватство, које би квалификовале његову биографију на тај начин да заслужи објављен помен. 
на матерњем говору Буњеваца и самим тим представљају сведочанство о једној специфичној националној култури. Најпре се појавио општеобразовни недељник Bunjevac (1882-?). Излазио је сваког петка, а у њему су објављиване препоруке за образовање и васпитање младих, путописи, корисни савети из виноградарства, пчеларства и пољопривреде уопште. Уследила је прилично дуга пауза у објављивању буњевачке штампе. Тек 1927. године излази недељник Vojvodina чији је власник, уредник и издавач био Ернест Бошњак. ${ }^{16}$ Војводина је била политички лист Буњевачко-шокачке странке. Осим текстова који су пропагирали ову странку, у рубрици Којешта објављиване су кратке приче или писма читалаца, а могле су се прочитати вести, односно локална хроника, новости из привреде и економије и временска прогноза. Неки од текстова су превођени и на мађарски језик.

Након што смо учинили и овај кратак преглед периодике која је излазила на буњевачком, приводимо крају анализу и приказ Наших новина. И мада при речи о језику хрватском и/или говору буњевачком коришћеном у овим новинама немамо за циљ постављати лингвистичке смернице указујући на недоследности и нејасноће, будући да у време када је излазио лист буњевачки језик, за разлику од хрвтаског језика, није био стандардизован, можемо констатовати да је реч о писму и језику у потпуности разумљивом говорницма српског, хрватског, буњевачког и шокачког народа. Но, како је више него јасно да је сасвим разумљив и просечном читаоцу код нас и данас, слободно смо издвајали наводе и указивали на оно што јесу наважније каратеристике листа, на тај начин описујући и уредничку политику. Према томе, крајња намера аутора овог рада је била да приказујући лист, политичко деловање и улогу главних актера укаже на понашање одређених суграђана и група које су у тим ратним годинама вршили веома снажну и системски организовану кампању у сомборској средини и насељеним местима а међу популацијом, како се у самим новинама наводи, превасходно Буњеваца и Шокаца. Дакле, закључак који можемо стећи читајући и фототипију у прилогу који следи и овај рад, односно приказ, јесте тај да су Наше новине служиле, пре свега, борби против декроатизације Буњеваца и Шокаца, исто колико и намерама јачања и ширења кроатизације, опет Буњеваца и Шокаца, настањеним вековима уназад на подручју западне Бачке у време окупације ових северозападних крајева Краљевине Југославије од стране нацистичке Мађарске.

16 Више о овоме видети у: Копоран, Г; Плавишић, Н. (2015) Каталог изложбе Век и по сомборске штампе, Градска библиотека „Карло Бијелицки” у Сомбору, Сомбор: Билбордпринт. 


\section{Прилози}

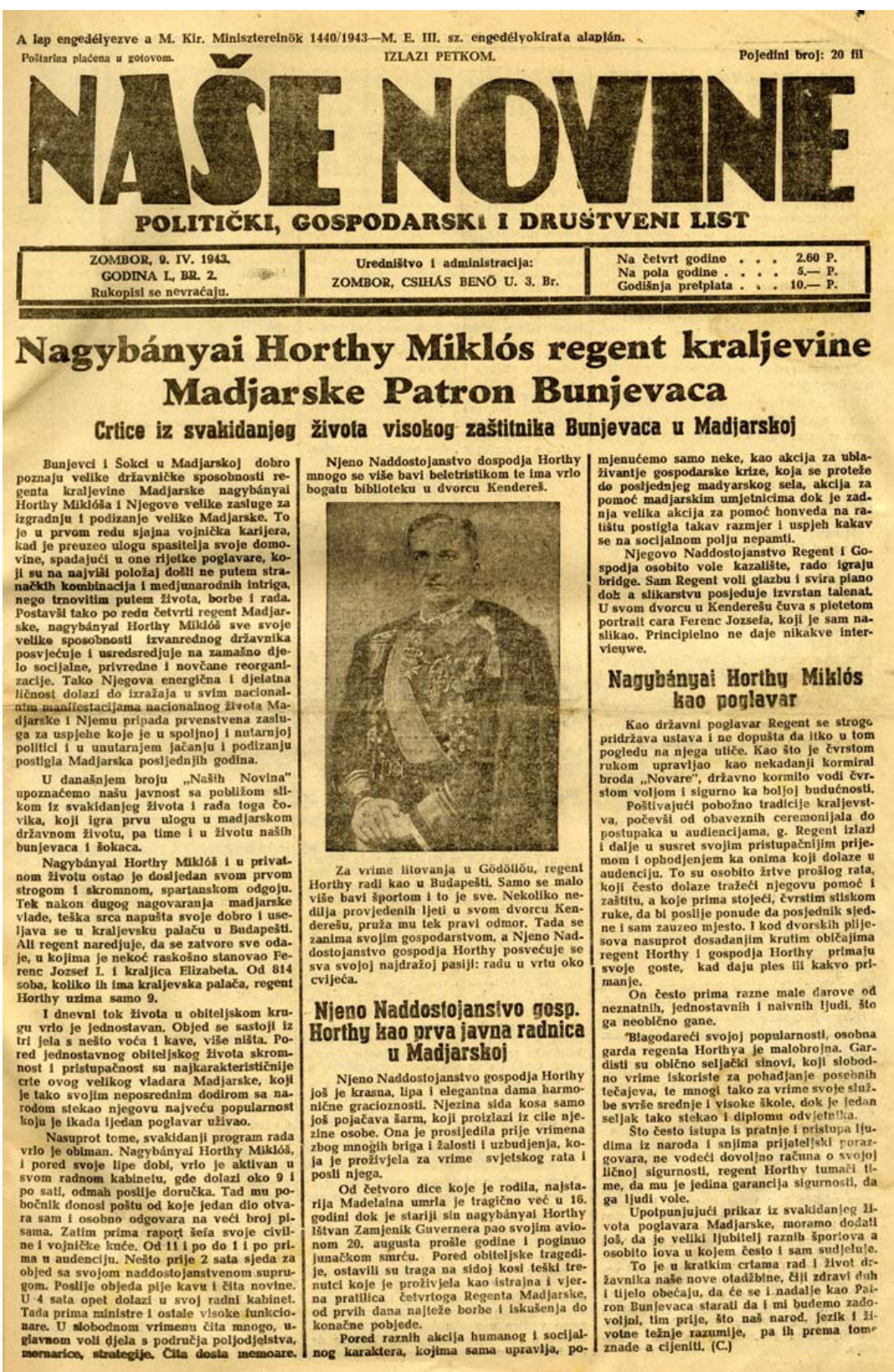




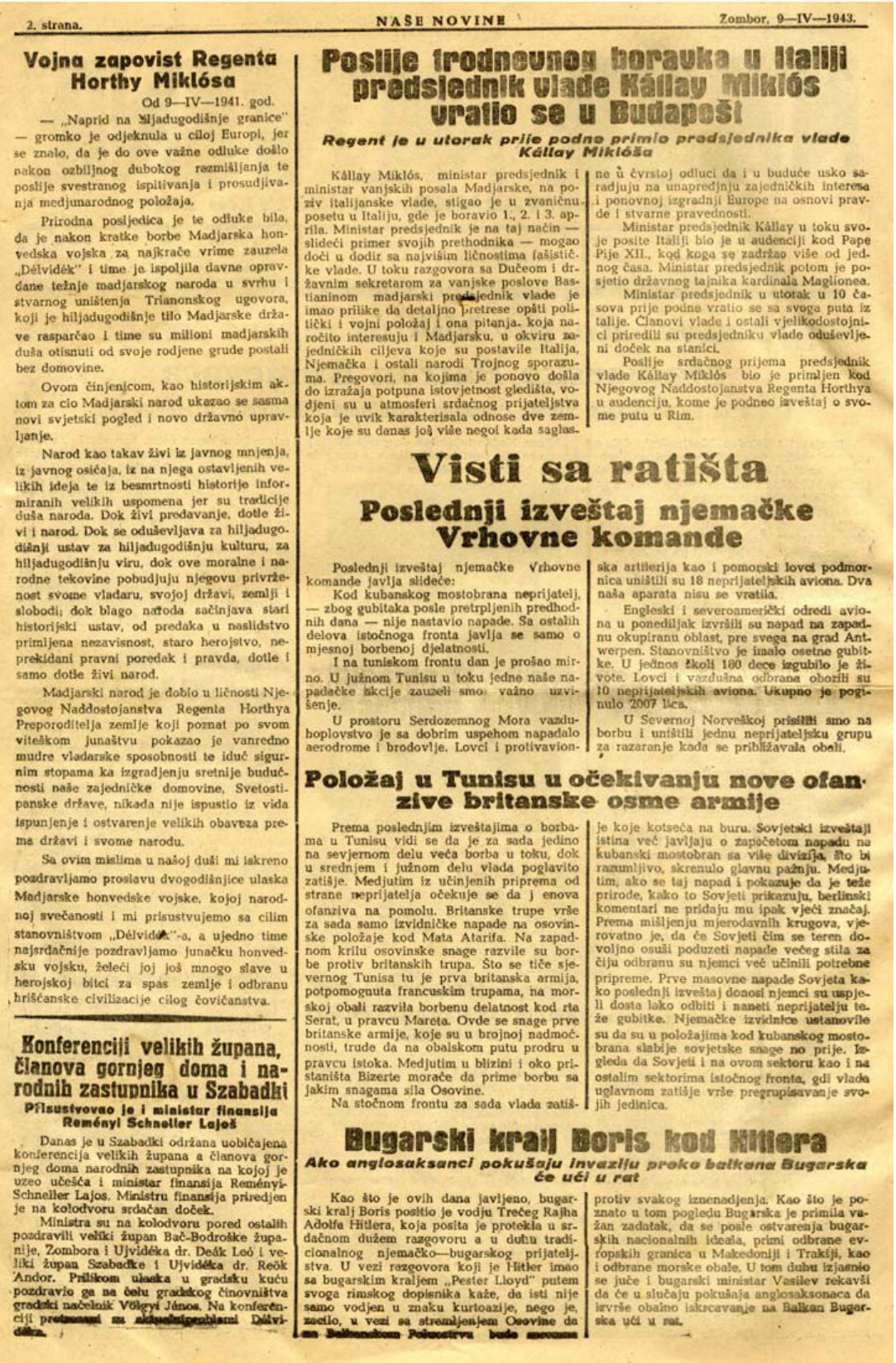

Прилог 1: Наше новине бр. 2 од 9.4.1943, стране 1-2. 


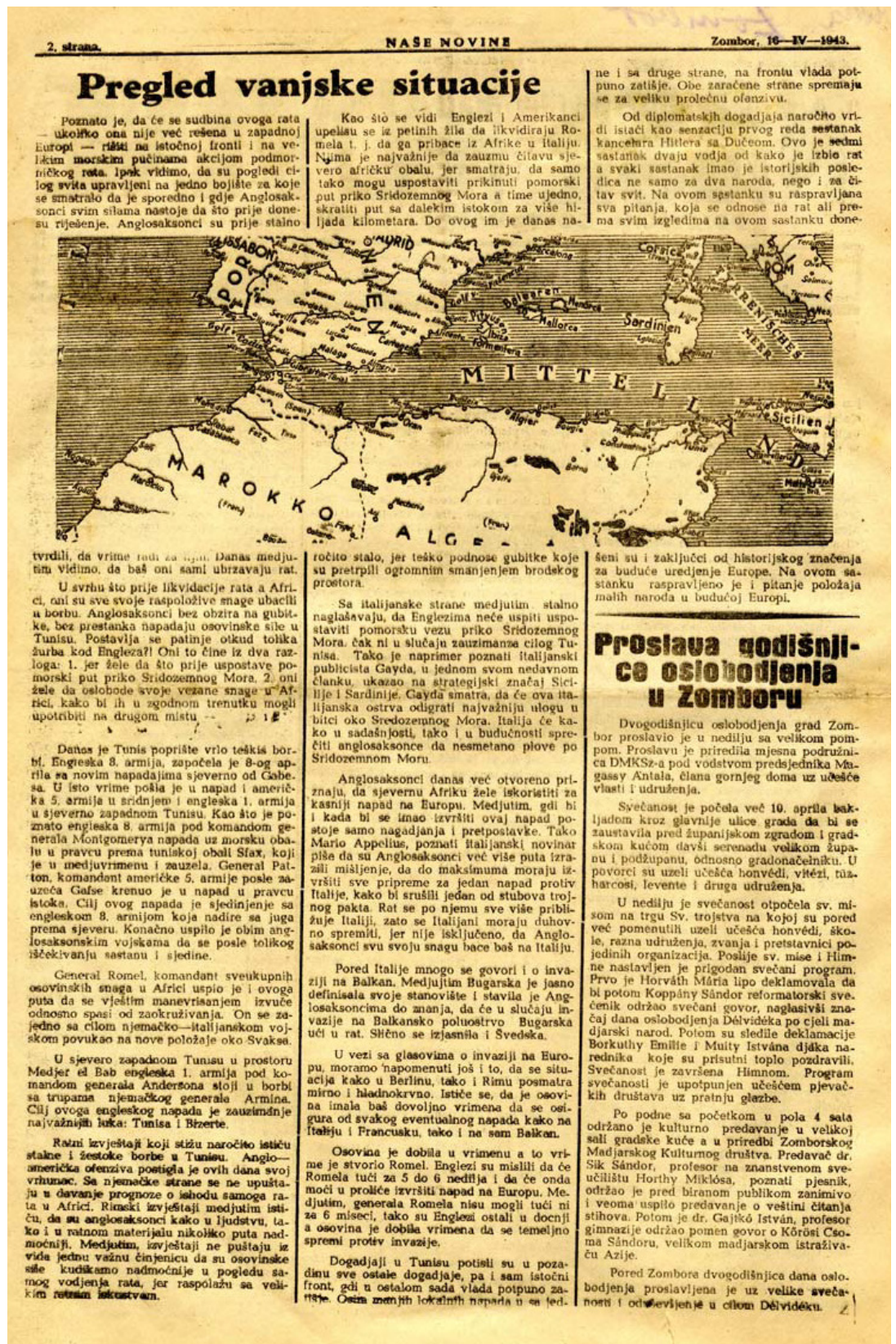

Прилог 2: Haше новине бр. 3 од 16.4.1943, страна 2. 


\section{Ideološki rat}

\section{Zabluda komunizma}

\section{Protiv liberalnog gospodarstva, gdje} vladalo načelo fair laisses fair passe, șto ce reCi: pusti neka ide kako ide nadolazi jedna strašna reakcija. Ova se reakcija poja. vila prvo medju samim naučnim krugovima. Javljaju se pojedini naučnici, koji su već u samom začetku liberalno-kapitalistic kog gospodarstva uočlli velike slabosti ne-
ograničene političke I gospodarske slobode. Sama ličnost, kao i interes i sloboda pojeSama ličnost, kao í interes $\mathrm{i}$ sloboda poje-
dinca bića je podignuta na najviši moguéi dinca bića je podignuta na najviši moguć
stepen, Pri tome se izgubilio iz vida, da baš stepen. Pri tome se izgubillo iz vida, da baš
ta prikomirna sloboština, da ne kažemo slata prikomirna sloboština, da ne kažemo sla.
boština nosi u sebi začetak svih moguéth za. la. Zellia se osigurati sloboda pojedinaca ali Je bas̆ pojedinac zahvaljujuéi toj slobodi dosao u politicku a što je joș gore u materljalnu, društvenu I kulturnu zavisnost prema drugom pojedincu. Ova vlast pojedinaca nad pojedincima ćesto je blla tako teška da je ona liéla na neko moderno ropstvo.

Reakcija koja se pojavila protiv ovog istema bila je potkrepljena naukom. Pojav ljuje se prvo jedan naučnik, koji je kritičim i filozofskim posmatranjem uočio jedkog gospodarstva. Svaki bi otkrio neku golotinju u sistemu. Tako je to islo postepeno, dok se nije pojavio jedan Jevrejim, koji je sobrao sve primjedbe učinjene protiv sistema I tako je postavio svoju opcu kritiku društvenog sistema. Tako se eto rodio socijalizam iz koga se kasnije stvorio 1 sam komunizam.

Komunizam odnosno marksizam, - ka. ko ga neki nazivaju po tvorcu socijalizma Jevrejinu Karlu Marxu - ostvaren je u djanske drżave - kao sušta protivnost gramokracifl. Komunizam - suprotno od de ralne demokratije, koja daje čovjeku sve stto je ovaj stekao svejedno da il na pošten ili na neposten načln, da Hi sa radom ill špe. kulacijom - oduzima čovjeku sve: slobodu, imovinu, obitelj, vjeru, narbadnost 1 kulturu. Sve ove vridnost odbacuje komunirijalna dobra koja su opet vlasnaçuje mateJedinaca, nego neke nazovi driave. Sva proizvodna dobra dakle, zemlja i fabrike postaju isključivo vlasniśtitvo države. Svi oni koji rade 1 obradjuju zemlju, kao $f$ oni koji rade po tvornicama i fabrikama postaju radnici no službi države. Radnik pak ima pravo jedino na svoju żivotnu egzistenciju tj. toliko
da żivi. On nema pravo nosno kapitale, U komunizmu nevinu odprivatnog vlasništva.

Komunizam zabacuje slobodu. Umjesto slobode on postavlja diktaturu i to diktaturu proletarijata. Drzavom vlada komunistićka partija kao pretstavnik radnićke klase tj. svojim ju. Stvamu vlast u državi ima

tije - jevrejl. temelja đanašnje civilizacije. propovijeda slobodnu ljubav, Brigu i staraWle nad djecom rodjene u ovakoj ljubavi priuzima na sebe drzava, jer se odgoj djece diteljima. Djeca se odgajaju u državnim dječfim zavodima da bi se već u najranijoj ml eljit, jer se obj.

\section{SCHEURER GASP'AR}

ajjozija i draguljar

ZOMBOR, PetSh ul, 13 Telofon, 205 telj smatra za kulu konzervativizma. Ova njera komunizma upravljena je u prvom re. du protiv seljastva, fer je seljastvu temelj
baš seljačka obltelj i seljaćki dom. Razbije-

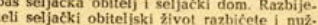
o seljacki staleź

Komunizam zabacuje viern. Mjesto vje ¿́ ima da zavlada bezboźje - Mjesto vjemjesto Božje svemoći viruie se u svemoc radnickog proletarijata. Zakon proleterske moći ima da zavlada nad Božlim zakonima. Vjera se sprečava policijskim mjerama: za. tvaranjem crkava, samostana $j$ progonstvom vecenistva a i propagandom putem stampe. Komurata ideju i nacionalnost uopće. On propovje. dainternacionalizam. Komunizam smatra nacionalizam za svog najvećeg neprijatelja. Zato se u Sovjetskom Savjezu nacijonalni pokreti najenergičnije. uniśtavaju. Kao primjer spominjemo samo Ukrajinu, gdje je naKao sto smot potpuno iskorijenjen. omunizam je antheza libera mogli vidjeti tiji. Komunizam unistaya vjeru privatno vlasništvo obitelj $\mathrm{i}$ naciju. Dakle on unišs. tava sve one vrijednosti na kojima se temejii civilizacija ljudskog roda stećene na hisamo jedinu vrijednost a to su materijalne samo jedinu vrijednost a to su materijaln no materijolis komunizmu vidimo potpagova nastrašnija zabluda nalozi se bas tome, da on smatra materiju - styari com od duha. Kod njega sve počlva na sil na diktaturi proletarijata.

Komunizam ne priznaje privatno vlas uistvo. 1 ovdje vidimo jednu strašnu zablutva medjutim drzavno vasnistvo. iz iskistvo níkada ne donos! takav prinos kao prtvatno gospodarstvo. Veliki procesi i sudje aja u Sovjetskom Savjezu, gdje su optuživani selyaci zbog nemarnosti, nerada i sabotaže samo jos̆ više dokajuzu, da je ustanova kolektivizacije ne naravna. U komuniz da seljaci rade po silijative a to ce reci, svom najboljem po sili po komandi a ne po jek - selyak - radi za sebe za svoju djecu Sa voljom se pak radi tamo, odje covjek zna zasto radil Moramo se upitati da li će covjek raditi sa većim mazom $\mathrm{i}$ brigom svo ju fili državnu zemlju $i$ to onu zemlju koju mu je država otela?

ost 1 adalje komunizam zabacuje nacijonal. je neprirodno. Coyjek kada se rizam. I to da obitelji. Obitelj u užem smislu cini familiju, a familija tvori pleme, narod - naciju. Veza je ovdje krvna, rasna i pravna. Danas vidimo da baš ova krvna 1 rasna veza ima narocitu snagu, jer nikada nacijona. Intere bio tako jak kao u nase danel Innes linde ja je komunizam prido. ušao je u duśe ne samo radnllka već i mno i nezadovolinika. Danas se medjutim sve asnije uvidjaju teške zablude ovoga si stema. (Nastavi ce se)

\section{Vukičević S. i Drun}

gvoždjaraka radnja ZOMBOR

Osnovana 1950 Teleton : 73

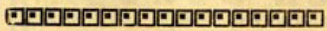
Oglašui u našem listu

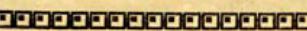

\section{Naš i iazis}

Ovih dana sam se srio sa jeclnim svofit kolskim drugom, sa kojim se već dugo roli smo us syemu i svačem. Rijećt te pazcov. ravno is o nałim novinama. Mec je pala nc eli je primjetio da je nezgodno sto se Nasim Novinama" ne upotrebliava doslie no samo jedno narijećje, pa bila to ikav? ta ul ijekavitina. On je bio misilienjo. kavicu triba potpuno napustiti, jer da je n azo bi se nużno uzimati rijeżi iz ifekavice bi tako nastala nepotrebra zbrik Ove misll moga prijatel ja duboko su ojmile, pa sam se o ovome našem jezlénnt Svi dugo mislio,

Svi mi znamo, da Bunjevci govore kavicom. Sa ikavicom govori i većina govori sa i jekavicom. Prema nase Soka se pitanje kako se može plsati u bustav ošokaćkim novinama? Odgovor ie suvite ednostavan. Pisali se moźe iskijucivo kavštinom ill sa ljekavsstinom, jer se nt moźe a i smije samo narodnim jezikom sati se mora onako, da narod razumije is

Kada smo već kod ovoga pilanja. mo ci $t$ j. sto o tome govori filologiia. Sjectam jednog interesantnog slucaja, koji se det. u osmom razredu gimnazile, Ravnateli gim nazije bio je jedan priznati stručnjak, Fllo. log. Kada ga je jednom prilikom jedan djor fina ill ilekays pravilan govor: da li ikavda je pravilno govoriti i pisati sa jednim sa drugm dijalektom. Uvijek se mora paziti kako govori narod, pa prema tome tako se mora i pisati, jer se u ostalom za narod pise Postavlja se pitanje może li se usvojit: anoviste moga prijatelja, da našu lijepu kavstinu potpuno ispustmo kao službent naś jezik jedino ijekavštinu, to i saradnika koji pišn sa ikavicom ispravli mo na ijekavštinuš Moje je misljenje da to ne možemo i nesmijemo raditi, jer bi to bio upravo grijeh prema proślosti $i$ śto je vaż. nije prema samom narodu. Ikavśtina je lips milozvućna, pa prema tome nemamo se eka stidit, ako sa ikavstinom govorimo radije ćitati jedan clanak pisan ce mnogo nego kojim drugim narijecjem pa prema to. me nemamo ni prava ní razloga da se fikavi. ce odreknemo.

Medjutim, sasma je drugi slučaj sa na. Som Sokadijom, koja govori sa ijekavicom Ona rado cita ijekavicu, Jer tako í govor Prema tome, postavlja se pitanje kaki da se pise u novinama. Mok je misljenje da se ima oslavitl potpuna sloboda. Svak: ima pravo, da piše onako kako on zna i ka. ko je kod svoje kuće naučio povorith Plsati se moje podjednake: sa ifekavicom I sa ikavicom. To je u ostalom nama svima jasno pa se toga moramo I drżati.

Zato, neka u buduce nikome ne bud krivo, kada se piše sa ikavicom ili sa ljeko vicom. jer je ona podjednako nasa. Potrudi mo se, da ne stavljamo dlaku na jaje ko da je već nismo našli u samom jajetu.

N. N.

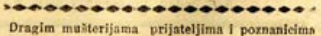

Prijatne usikringle praznilee toll

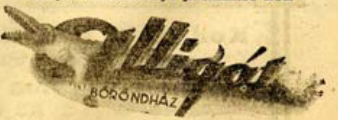

Vlasnik : Zstgmond VIImon, ZOMBROB Clan Bizalotn-a PETOKI 8 TELEFON: 309

Прилог 3: Наше новине бр. 4 од 24.4.1943. страна 6. 


\section{,MADJA ARSKI USKRS}

Ministar narodne odbrane Antal István održao je govor na radiu misije madjarskog radija, odrzao je govor se od očinske ruke kralja Svjetoga Stipana ministar narodne odbrane g. Antal István o madjarskom Uskrsu. Naglasio je u svome govoru, da je Velika subota dan uskrsnuća arakteristican madjarski prazmik. Vekovima je ovaj narod nebrojeno puta sticao svo.

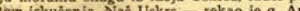

\section{Poglavnik Hrvatske Ante Pavelić kod hitiera}

Vodja i kancelar Rajha Adolf Hitler pri- | ve, Mussolini, regent Horthy, Quisling nornio je u svom Glavnom stanu Antu Paver.

, To vé sedma dríava koja pro

a šefa, odnosno državnika uzima učesćca prolećnim diplomatskim akcijama osovine. Dosada su ovi poglavari, odnosno drżavnici posjetill Hitlera u Glavnom stanu: Boris bu

\section{Telegram dr. Mile Budaka novog hrvatskog ministra Kállay-u}

Novi hrvatski ministar za vanjske po- $\mid$ sjedniku vlade I ministru vanjskih posala o slove dr. Mile Budak, prilikom stupanja na Kallay Miklósu.

\section{Ratni gubitci Sjedinjenih Držaua}

Prema izveštaju iz Wasingtona, severo- I ranjenima i zarobljenicima iznose 51.600

\section{Poslanstuo Siedinjenih Držaua \\ iz Helsinkia seli se ut Stokhoim}

Kako obavestajne agencije javljaju Po- otselio. Britanska obaveśtajna slużba tvrci slanstvo Sjedinjenih Drżava dobilo je nalog prošle nedilje veći dio ćinovniśtva se već nema novoga momenta.

Otvara se izložba za ratno snabdevanje u Poljoprivrednom Muzeju u Budapesti Drž. Chemički Institut prilikom 60, godišnji- $\mid$ d. Sa praktičnog gledišta vrlo ce poučan bit ce svog opstanka i u Poljoprivr. Muzeju, ko- onaj dio izlożbe, koji se bavi pitanjem ekoji se nalazi u Városliget-u, priredjuje intere- nomičnog gojenja svinja, dalje susenjem santnu izložbu. Na toj izložbi u naturi u stoćne pice Osim gore navedenog daće se is

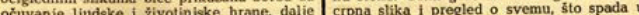
biće prikazana važnost i uloga vitamina u okvir današnje ratne ishrane. Izlożba se vezi sa današnjom ishranom. Posebno mjesto otvara 16-og maja ove godine I zbog svoje ce imati na izloźbi uljano i vlaknasto bilje, dalje sve u vezi sa aktualnim pitanjima go-

\section{Viliki uspjeh Karagićeve glume "Svijest" u Bácsalmásu}

Bunjevačka kazališna omladina u Bács- Kao Roza, Katica Ninčević u ulozi Zlatic almásu priredila je prvi dan Uskrsa 25. aprila vrlo uspjelu kazalisnu predstavu. Na rasporedu blo je Karagicev poznat kazališni komad gluma iz bunjevackog narodnog zivota u moralnom tako i u materijalnom pogledu vanredno uspjele. Predstavljači f predstayIfacice shvatili su ozbilino svoje uloge i svi do jednog uživjell su se u njih tako da je cijela dramska radnja toga nasega najbolje. ga nacionalnog komada bila jecna cjelina. ama bogodana glumica. Mariska Jambo Mara), Katice billa je zlatna. Matija Petric, Ana Piuković, Joso Bende, kao Peić, posve prirodan je bio, Antun Prikidanović (kao Mate) odglumio je pravog pravcatog seo skog trgovca Mrane, Laza Horvat, bio Je vrlo dobar u ulozl nagle ali popustijive naravi Grge, Boro Lazarevie, kazi dida Marka

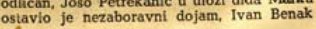

u ulozi Dr.-a Wilda blo je tragikomična figura, koja je razveselila odusevijeno opcinstvo, a narocito Joso Piuković nasmijao je razdraganu publiku u pijanoj ulozi Kantora. cigani tin su svi na mjestu 5 kojima se rija Delić, Joso Mohai, Mate Prikidanović Buli su dobri i mali Joso Rudić (Jaśica), te Pajo Prikidanović i Vranje Petrekanić.

Takva lijepa i vrlo uspjela kazališna predstava ima vrlo dubok narodno-prosvjetni značaj. Kako je poznato naș ondeśnji na vini uvażeni g. Antun Karagić osnoveo je prije 12 godina kao 17 godišnji mladlé prvo u Madjarskoj. Ne dugo po njegovu prim jer propagandi počela se po svim nasim seltma osnivati društva kazaltšnih dobrovolja ca. Sada nema već ovdje sela gdje se ne bl od vrimena do vingena priredjiva bi od vrimena

Volnıtki Ulležnik

1 budućnost ratnih ranjenika

Zadaća je bolnickog zbora svake vof. ske, a osobíto vojničkog lječnika, da se u posljedica nesreće na bojištu. U lakšim slućajevima briga svršava u trenutku, kad za. cill rana. Drugćije je o onim vojnicima. koje je njihova rana ili bolest izbacila iz gradjanskog zanimanja. No takovih slućajev ovaj rat ne pok

Triba raalikovati medju onima, koji su izgubili udove 1 onit, kojl su pretrpil stet. Vojnički lječnilk prave moderne vojske tri. ba prouccavati mogućnost kasnijeg uposije. aja dotičnog ranjenika. Tko je ingubio dešnu nogu, ne dolazi u obzir za stanovite po. slove. Ne će modi nositi teśke terete, ne ć

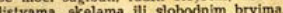

Drugi slučaj, koji traži u jos većoj miri strućnu procinu: povridom mozga ili oboljenja unatarnjeg tha, boless ćovik ne raditi na skelama, listvama, brvima, dizalicama, ali ne smije raditi ni kod otvore nilh vrata, nad kotlovima, nad vodom filf kod strojeva, koji se brzo kreću.

Tako se moźe navadjati niz primjera koje vojnićki lječnik triba uzeti u obzir. Prijaśnji pojam, ,skkrbi" imao je nesto pri2ve po sajo je danas dobio mnogo plemenitíl znaciaj. pritvorenu zahvalnost drźave I naroda, sto je za njîh časna dużnost.

Invalid triba načelno biti smišten bilic u starom ill u novom urednom zvanju. Naopako bi bilo, kad bi se htillo, da invalic uče krasopis, pravopis, stenografiju, pisanje na stroju, a moguce lakodjer gramatiku povist. Time bi costo do preplesecenja ponude trgovačkih 1 uredsi iz silat not cóa sa zdravim silama u zvanjima sa previse po-
nuda. Jednako je važno, da fnvalidi buut opet uvižbani za svoje zvanje fill za koj novo zvanje. Vojnicki ljecnik ime zhon toga odman pristupeli svim miram mu stoje na rajerno uredjenoj državi, i nie gova je dužnost, da onesposobljenog rate í̉ osposobi za aktivni stvaralaćki rad u narodnoj zajednici.

Casna je dužnost ćtavog naroda, da of rori povoline moguenosti za buduenost oni koji su za svoj narod żrtvovali zdravlje dilove svoga tila. Vojnicki se ljectnic osobito vižbaju u poznavanju ljudi i njihova je ćasna dużnost. da se prihvate poel za spas budućnostl ratnih invalida.

Прилог 4: Haше новине бр. 5 од 30.4.1943. страна 3. 


\section{Литература}

Наше Новине, сви бројеви http://www.biblioso.org.rs/digitalna zbirka.php?!ng=ci Копоран, Г; Плавишић, Н. (2015) Каталог изложбе Век и по сомборске штампе, Градска библиотека "Карло Бијелицки“ у Сомбору, Сомбор: Билбордпринт.

\section{Vladimir Jerković}

\section{NAŠE NOVINE ${ }^{17}$ : POLITICAL, ECONOMICAL AND SOCIAL MAGAZINE 1943-1944}

\section{Summary}

Naše novine were, prevalently, a political magazine that contained columns from the fields of economy and social topics. The primary objective of this magazine was strengthening the ongoing croatization of Bunjevac and Šokac people during the occupation of Sombor in the World War II by the military forces of Hungarian fascist troops. The magazine was published in Sombor from the $2^{\text {nd }}$ April 1943 until the $6^{\text {th }}$ October 1944. The conceiver, publisher and editor of this magazine was Grga Vuković, a lawyer from Sombor. This magazine can be found in the fundus of local periodicals in the City library "Karlo Bijelicki" in Sombor and it represents a certain reminiscence of the times and particular, mostly nationalistic, as well as political goals that were approved by the occupying forces so as to make the Bačka region, at least seemingly, a Croat historical and national domain, just as Srem region factually had become since it was a part of the Independent State of Croatia (NDH). The articles any reader may come across represent an evidence of the maltreatment of certain national and ethnic groups with the objective to re-qualify some deeply rooted ethnicities that existed in this area for centuries. The most influential Croat part of the times (HSS) did it in order to convert Bunjevac and Šokac people into Croats. The pursuits of Grga Vuković not only in this magazine but also as a representative in the Budapest Parliament and as a journalist was directed towards awakening Croats ' national awareness, warding off decroatization of the aforementioned ethnic groups and arranging the best possible relations with the fascistic government, as it is quite evident in the contents of this magazine. The author of this article tends to enlighten this part of Sombor, but also national history, the author's intentions are to emphasize the tendencies this magazine had been creating throughout its

17 In English the translation of the magazine would be Our newspaper. 
columns and the role it had in the war times so as to preserve from the oblivion some historical facts quite important for a better and more correct understanding of contemporary issues and tendencies we face within the domain of political activities of some representatives and associations of ethnical minority in the Republic of Serbia nowadays.

Keywords: Naše novine, dr Grga Vuković, Croats, Šokac people, Bunjevac people, Sombor, World War II. 